by an extensive experimental investigation that the method of very slow decompression was in some respects actually harmful. He also proved that a method of 'stage decompression' was both safer and quicker. He calculated tables for regulating the safe rate of decompression of divers by stages corresponding to the pressures to which they had been exposed and the duration of their exposure. He again took up this problem in 1935 and worked out tables for still greater pressures. His stage decompression is now generally used and has undoubtedly saved many lives, besides making it possible for divers and tunnellers to work at pressures otherwise unattainable.

Haldane gave a full account of his work on the physiology of respiration and of some of his investigations in applied physiology in his Silliman Lectures, which were published under the title "Respiration" in 1922. A new edition, to the rewriting of which he devoted much time and care, appeared in 1935. In this book, unrivalled since it first appeared, he has left a record worthy of his genius.

Haldane was created a Companion of Honour in 1928 in recognition of his scientific work on industrial hygiene. The many other honours which he received, and which are recorded elsewhere, included the Copley Medal of the Royal Society in 1934.

Only a few weeks before his death, which occurred after a short illness on March 14, in his seventy-sixth year, Haldane had returned, apparently in good health, from a visit to Persia and Iraq, whither he had gone to study heat-stroke.

Haldane's influence on all aspects of physiological thought has been enormous and his loss is not only a bitter blow to those who knew and loved him, but also leaves a gap in the application of physiology to industrial and medical problems which will indeed be hard to fill.

J. G. P.

\section{Mr. Maurice C. Macmillan}

A MONTH ago we recorded with much regret the death of Mr. George A. Macmillan, one of the directors of Messrs. Macmillan and Co., Ltd., the publishers of Nature. Another link connecting the journal with this publishing firm has now been broken by the death on Monday last, March 30, at eighty-two years of age, of Mr. Maurice Crawford Macmillan, brother of Sir Frederick Macmillan, the chairman of the company, and cousin of Mr. George Macmillan.

The firm was founded in 1843, when Mr. Daniel Macmillan, the father of Sir Frederick and Mr. Maurice Macmillan, was joined by his younger brother Alexander and published the first volume with the name of Macmillan on the title-page, namely, A. R. Craig's "Philosophy of Training". Seven years later the firm adopted the title Macmillan and Co., which it has retained ever since.

Mr. Maurice Macmillan entered the business in 1882, after a distinguished career at Uppingham and Cambridge, followed by five years' experience as an assistant master at St. Paul's School, under Dr. Walker. $\mathrm{He}$ devoted himself particularly to the educational side of the business, and to him is largely due the comprehensive list of standard books for students of all standards and subjects published by the firm. He was keenly interested in every aspect of educational work, from the primary school to the university, and he followed with close attention all developments in methods of teaching scientific and other subjects. He was chiefly responsible for the establishment of branches of the firm in India, Australia and other centres where the educational publications of the firm are largely used.

Though Nature was founded several years before Mr. Maurice Macmillan came into the firm, he was always an encouraging supporter of it and was keenly interested in many scientific subjects dealt with in these columns. In this, as well as in the selection of books of high standard, he rendered valuable service to science, and we pay a grateful tribute to him for his great work and beneficial influence over a period of many years. He leaves three sons, two of whom, Mr. Daniel Macmillan and Mr. Harold Macmillan, M.P., are directors of the firm.

Mr. GeORge Hubbard, a London architect of distinction, who was twice a vice-president of the Royal Institute of British Architects, died at his residence at Eltham on March 19, his seventy-seventh birthday. Mr. Hubbard was well known as an archæologist and collector of antiquities. His most noteworthy contributions to archæological studies were a paper on "Architecture on the Eastern Side of the Adriatic", and in prehistoric archæology a book written in conjunction with his brother, A. J. Hubbard, on "Neolithic Dew Ponds and Cattleways", published in 1905, which went far to settle finally the problem of the construction and uses of this primitive method of dealing with deficiencies of water supply.

WE regret to announce the death at the age of sixty-nine years on February 27 of Prof. Charles Jules Henri Nicolle, for more than thirty years director of the Pasteur Institute of Tunis, and professor at the Collège de France. $\mathrm{He}$ is best known for his work on typhus, which in 1909 he proved to be transmitted by the clothes louse. He was also a pioneer in the prophylaxis of this disease and of measles, in addition to much valuable work on other infectious diseases, for which he was awarded the Osiris Prize of the Institut de France in 1927, and a Nobel Prize in 1928. Prof. Nicolle was a member of the Paris Academies of Sciences and Medicine, and an honorary fellow of the Royal Society of Medicine.

WE regret to announce the following deaths :

Sir Archibald Garrod, K.C.M.G., F.R.S., formerly regius professor of medicine in the University of Oxford and consulting physician to St. Bartholomew's Hospital, on March 28, aged seventy-eight years.

Sir Joseph Petavel, K.B.E., F.R.S., director of the National Physical Laboratory, Teddington, on March 31, aged sixty-two years. 